\title{
Strengthening the Agriculture Sector as a Locomotive of Economic Development in Border Areas Indonesia- Timor Leste (Study TTU Regency)
}

\author{
Egidius Fkun ${ }^{*}$, Magdalena Sunarty Pareira ${ }^{2}$
}

\author{
${ }^{1,2}$ Universitas Timor, Indonesia \\ Corresponding Email: egifkun6@gmail.com
}

\begin{abstract}
This study aims to determine policies to strengthen the agricultural sector as a locomotive for economic development in border areas. In border areas, problems related to agriculture are low productivity, weak market access, very traditional farming patterns, weak post-harvest processing, and common agricultural resources. The method used in this research is the literature method through a study of various literature. The results showed that to make agriculture a locomotive for economic development, what was done were: 1) changing the mindset and mental and behavior of the farming community; 2) Mapping the potential of each sub-district; 3) Integrated agricultural development and 4) Increasing production and productivity through the Food Labor Intensive pattern (PKP).
\end{abstract}

\section{Keywords: Economic development, Agriculture}

\section{INTRODUCTION}

Indonesia is an agricultural country because it has the potential for significant farming resources and has many workforces who still depend on the farm sector. From resource potential, Indonesia's terrestrial biodiversity is the second largest in the world after Brazil. This can be seen, among others, from the various types of food crops, horticulture, plantations, and animal husbandry commodities that the community has cultivated for a long time as a source of food and the economy. Meanwhile, from labor, the agricultural sector is the most absorbing business sector, namely more than 38.05 million people. Therefore, the wealth of natural resources in Indonesia should be an opportunity to develop the agricultural industry to support people's lives. Consistent economic growth in agricultural development is a mandatory requirement for Indonesia to consistently carry out agrarian development.

Several research results, among others, Mellor, stated that the critical role of the agricultural sector in economic development lies in several things, namely the support of economic growth and the provider of national employment; providers of food needs for the community or residents of a country; foreign exchange earner; Driving the development of the industrial sector; and poverty alleviation and welfare of rural communities. The results of other studies suggest that some of Indonesia's exports also come from the agricultural industry so that the agricultural sector plays a role in absorbing labor and providing food and clothing for the population. Nadziroh also examined the part of the farm sector in economic growth, including: as a food producer sector; as a source of labor for other economic sectors; as a source of foreign exchange for the country; increasing demand for industrial products and thus encouraging the expansion of the secondary and tertiary sectors.

Faced with this condition, it requires a clear and focused direction of agricultural development policies from the government, both at the central and regional levels. Government policies related to agriculture must be directed at increasing agricultural productivity, which will contribute to maintaining community food security and improving farmers' welfare. Agricultural policy should be directed at improving the economy. The agricultural sector must be positioned as the mainstay of the economy. This is intended to minimize problems that arise: neglected agricultural infrastructure, more minor functioning farmer organizations, marginalized farmers, high imports, low investment, weak market access, and weak access to financial institutions.

One area that also pays serious attention to improving agriculture in the District of North Central Timor, which geographically borders Timor Leste's land. The agricultural sector has dominated the structure of the regional economy in recent years. The 
contribution of the farming sector to Gross Regional Domestic Product (GRDP) in the last three years for the top 4 business fields can be seen in the following table:

Table 1. Distribution of Percentage of PDRB in TTU Regency at Current Prices

according to the Business Field 2017 - 2019

\begin{tabular}{|c|c|c|c|}
\hline Business field & 2017 & 2018 & 2019 \\
\hline (1) & (2) & (3) & (4) \\
\hline $\begin{array}{l}\text { Agriculture, Forestry, and } \\
\text { fisheries }\end{array}$ & 40,73 & 39,91 & 39,56 \\
\hline $\begin{array}{l}\text { Government administration, } \\
\text { Defense and }\end{array}$ & 15,58 & 16,29 & 16,81 \\
\hline Social Security & 10,35 & 10,52 & 10,46 \\
\hline $\begin{array}{l}\text { Building } \\
\text { Education Services }\end{array}$ & 6,92 & 7,03 & 7,12 \\
\hline
\end{tabular}

Source: TTU Regency Agricultural Statistics 2019

Table 1.1 above shows that the agricultural sector is the leading regional sector (core competence) from year to year, namely 40.73 in $2017,39.91$ in 2018, and 39.56 in 2019 . This percentage is very high compared to other sectors, namely government administration, buildings, and educational services. That is why agriculture is used as a prima donna sector and is a top priority for regional development.

What is done by the TTU Regency Government is inseparable from the actual conditions of life of the local community who mostly rely on the agricultural sector and in this condition cause the community to live in limitations or poverty. Apart from that, another problem is the low ability of human resources to process existing agricultural products, resulting in an accumulation of the same goods in the market, which causes low prices, 2) underdeveloped economic growth centers (growth centers) in border areas, and 3 The community's access is still common to sell their products in the market, and the economic activities of the people in border areas are generally based on traditional agriculture which is oriented towards sufficiency. To overcome this, the agricultural sector must continue to be developed with various strategies by the local community's conditions.

There are many positive impacts of using agriculture as a supporting fact for economic growth. These positive impacts include absorbing a lot of workforces, fulfilling food security, increasing foreign exchange earnings, providing employment, obtaining added value and competitiveness, meeting domestic consumption needs, domestic industrial raw materials, and optimizing resource management. Natural resources in a sustainable manner.

This research specifically looks at the economic development strategy undertaken by the government of Timor Tengah Utara Regency by making agriculture a locomotive and seeing its impact on the community's welfare.

\section{METHOD}

The method used in library research (Library research). Library research is a type of research used in collecting information and data in depth through various literature, books, notes, magazines, other references, and relevant previous research results, to obtain answers and theoretical basis for the problems to be studied.

Library research has several unique characteristics, among others; firstly, this research deals directly with text or numerical data, not with the field or eyewitnesses, in the form of events, people, or other objects. Second, data is ready-made, meaning that researchers do not go anywhere, except the only face to face with sources already in the library. Third, library data is generally a secondary data source, in the sense that the researcher obtains data second-hand, not first-hand in the field. Fourth, the condition of the data in the library is not divided by time and space. This study uses secondary data obtained from books, literature, journals related to research problems. Meanwhile, the data source comes from the Central Statistics Agency of North Central Timor Regency in Agriculture Statistics 2019 and from Bappeda in the form of the 2016-2021 RPJMD.

\section{RESULTS AND DISCUSSION}

\section{Location Overview}

North Central Timor Regency is one of the districts in East Nusa Tenggara Province with a capital in Kefamenanu with 24 sub-districts and 194 complaints/villages. Kefamenanu has an area of $2,669.70 \mathrm{~km}^{2}$ and is occupied by 243,984 people with details of 120,990 men. Men and 122,994 women. The ratio of the people of men and women is not much different, and the distribution of the people in each region is relatively even.

From the regional aspect, TTU Regency is one of the regencies which directly borders with Timor Leste. The government's attention to this is to determine the City of Kefamenanu, namely the Regency Capital in the National Territorial Spatial Plan, as the policy direction for the utilization of state territory space. The city of Kefamenanu is classified into two areas, namely the Regional Activity Center (PKW) and the National Strategic Activity Center (PKSN). PKW is 
an urban area that serves to serve provincial scale activities or several districts/cities.

\section{TTU Agricultural Conditions}

In terms of agricultural land availability, of the total area of TTU Regency $(266,970 \mathrm{Ha}), 72.92$ percent $(194,700 \mathrm{Ha})$ is agricultural land. Then from the 194,700 hectares of agricultural land, an area of 14,269 hectares is rice fields. Meanwhile, 178,727 Ha is dry functional land consisting of moor, pastures, plantations, ponds, ponds, forests, etc. If it is further classified according to use, of the $14,269 \mathrm{Ha}$ of rice fields, there is an area of $3,811 \mathrm{Ha}(26.71 \%)$ of rice fields which in 2019 were categorized temporarily unused. Thus, overall agriculture in the TTU district consists of wetland agriculture and dry land agriculture.

Even though it has pretty large agricultural land, the production of food crops in the TTU Regency has decreased from year to year from the productivity aspect. This of course, has a direct impact on improving the welfare of the community. Apart from the erratic climatic factors that cause low rainfall, access to marketing is also the reason for the decline in agricultural productivity.

To overcome this, in TTU Regency, the fulfillment of the need for food is met by increasing the productivity of food plants which has been pursued through four types of activities. The four types of activities are intensification, extensification, diversification of agriculture, and rehabilitation of food crops carried out jointly and in an integrated manner. Also, to ensure the increase and continuity of production requires supporting variables such as quality human resources, adequate agricultural land, and sufficient irrigation.

\section{Agricultural Improvement Efforts}

\section{a. Agriculture as a Locomotive}

Efforts to improve agriculture in the TTU district are carried out by instilling and reviving the plan of making agriculture a locomotive for other sectors. The assumption is that advanced agriculture will attract developments in different fields, education will be advanced, health will be better, the environment will be sustainable and cooperatives, and SMEs will become more advanced. To support this plan, the DPRD also encourages by providing an adequate portion of the agricultural sector budget. Agriculture as a locomotive arises because many productive age workers are reluctant to work in the agricultural industry, but prefer to work in the service sector as motorbike taxis, which in terms of income does not significantly contribute to improving the community's economy. By making agriculture a locomotive, it is hoped that agriculture will become the driving force that can encourage people to prosper. Things that the government has done include conducting outreach, training, skills education for productive age workers to work in the agricultural sector.

\section{b. Mapping of leading potential in each district}

Furthermore, to be more effective, superior mapping was carried out in each sub-district. So far, the food crop sector is the primary production for food security and welfare for the farming community in TTU Regency. Thus, the local government continues to develop the productivity of superior agricultural products such as rice, corn, peanuts, and garlic through strategic programs, namely seedlings, fertilizer subsidies, and the provision of drugs against plant pests. Because the potential of the potential is spread across various districts, mapping the superior potential based on the sub-districts was carried out.

The research results indicated that rice crops were very potential to be developed in South Biboki District, West Miomafo District, North Insana District, and Biboki Anleu District. This type of food crop of corn can be developed in Miomaffo Barat District, East Miomafo District, Noemuti District, Kefamenanu City District, and North Insana District. Peanuts can be developed in Miomafo Barat District, Mutis District, East Miomafo District, Bikomi Selatan District, and Bikomi Nilulat District. Meanwhile, garlic is in the Miomafo Tengah sub-district.

c. Integrated agricultural development (combination with livestock)

An integrated agricultural system is a management system (business) that combines agricultural components, such as plants, animals, and fish, in a unified whole. The integrated crop and livestock farming system is a farming system characterized by a close relationship between plant and livestock components in a farming activity or area. For example, the cultivation of maize, stems, and leaves can be used as animal feed. Meanwhile, livestock manure becomes fertilizer for corn plants. So there is a continuation that never ends in the use of organic matter produced in farming. Thus, in the whole system there is an observation of the cost of agriculture and natural resources.

d. Increased production and productivity through the Food Labor Intensive Pattern (PKP) 
The Food Work Intensive Program is one of the strategies to improve the food for rural communities that are carried out to make the management of Raskin more effective and efficient by giving more weight through organizing farm families, working together to manage land for agriculture, mentoring, meetings, coordination, monitoring, and evaluation. The target achieved was a reduction in the burden of cash expenditures from 26,558 Target Beneficiary Households spread across 24 Districts to meet rice food.

\section{CONCLUSION}

The results showed that to make agriculture the locomotive of economic development, it is necessary to change the mindset and mentality and behavior of the farming community, mapping the potential of each sub-district, integrated agricultural development, as well as increasing production and productivity through the Food Labor Intensive (PKP) pattern.

\section{AUTHORS' CONTRIBUTION}

Economic development by placing agriculture as the locomotive of development is a favorable policy. The government shows its seriousness to focus on developing the agricultural sector. There are a few notes to note:

1. Agricultural development is not comprehensive from upstream to downstream. This means that agricultural product has been focused on the preparation of seeds, planting, fertilizing and harvesting. Farmers are facilitated by technology and assistance. But what lacks attention is postharvest processing. Therefore, it is necessary to improve post-harvest processing skills training.

2. 2. Another problem that has occurred so far is the weak market access to sell farmers' products. Of course, it is the duty of regional governments to find markets. One of the things that can be done is to work with BUMDES to become a market for people who sell their agricultural products, while at the same time turning on Regional Companies to become a market for BUMDES.

3. Many times, community agricultural products are also purchased by middlemen at low prices because of the lack of market access. Therefore, the government needs to issue local regulations to control market prices, especially those related to community crops.

\section{ACKNOWLEDGMENT}

The author would like to express his gratitude to the Head of the North Central Timor District Development Planning Agency, the Head of the Agriculture Service and several other OPDs who have been willing to provide information in this research.

\section{REFERENCES}

[1] Aryawati, Ni Putu Riska \& Made Kembar Sri Buddhi 2018. Pengaruh Produksi, Luas Lahan, dan Pendidikan Terhadap Pendapatan Petani dan Alih Fungsi Lahan Provinsi Bali. E-Jjurna Ekonomi Pembangunan Universitas, 7(9), 1918-1952.

[2] Kementan RI. 2020. Rencana Strategis Kementerian Pertanian 2020-2024. Kementerian Pertanian Republik Indonesia.

[3] Badan Pusat Statistik. 2020. Keadaan Angkatan Kerja di Indonesia Februari 2020. BPS RI.

[4] Widyawati, Retno Febriyastuti. 2017. Analisis Keterkaitan Sektor Pertanian dan Pengaruhnya Terhadap Perekonomian Indonesia (Analisis Input Output). Jurnal Economica, 13(1), 14-27.

[5] Arifin, Bustanil. 2005. Pembangunan Pertanian Paradigma Kebijakan dan Strategi Revitalisasi. Grasindo: Jakarta.

[6] Mellor, J.W. (ed) 1995. Agricultural on the Road ti Industrialization. The John Hopkins University Press, Baltimore and London

[7] Wibowo, Larasati S., (2012), "Analisis Efisiensi Alokatif Faktor-Faktor Produksi dan Pendapatan Usahatani Padi di Desa Sambirejo, Saradan, Kabupaten Madiun", diakses dari http://www.pustakapertanianub.staff.ub.ac.id

[8] Nadziroh, Mi'Rojun Nurun. 2020. Peran Sektor Pertanian Dalam Pertumbuhan Ekonomi di Kabupaten Magetan. Jurnal Agristan, 2(1).

[9] Apriyanto, Anton. 2006. Penmbangunan Pertanian di Indonesia Tahun 2004-2009. Kemenpan RI.

[10] Badan Pusat Statistik. 2019. Statistik Pertanian 2019. BPS Kabupaten Timor Tengah.

[11] Pemda TTU. 2016. Rencana Pembangunan Jangka Menangah Daerah Tahun 2016-2021. TTU: Kefamenanu.

[12] Listyawati, Andayani dan Lidia Nugrahaningsih Ayal. Kondisi Sosial Eknomi Masyarakat Kawasan Perbatasa Antar Negara: 
Kajian Masyarakat Kawasan Perbatasan di Timor Tengah Utara. Media Informasi Penelitian Kesejahteraan Sosial, Vol. 42, No. 1, April 2018, 37-50.

[13] Priyanto, Dwi \& Diwyanto, Kusuma. 2014. "Agricultur Development in the Borderline Areas of East Nusa Tenggara and Democratic Republic of Timor Leste". Jurnal Inovasi Pengembangan Pertanian, 7(4), 207-220.

[14] Kusumaningrum, Septiana Indriani. 2019. Pemanfaatan Sektor Pertanian Sebagai Penunjang Pertumbuhan Eknomi Indonesia. Jurnal Transaksi, 11(1).

[15] Yaniawati, R. Poppy. 2020. Penelitian Study Kepustakaan (Library Research), (Makalah) FKIP UNPAS: Bandung.

[16] Zed, Mestika. 2004. Metode Penelitian Kepustakaan. Pustaka Obor Indonesia: Jakarta

[17] Nalle, Frederic W dan Anastasia M. Giri. 2020. Analisis Pemetaan Sektor Unggulan Di Kabupaten Timor Tengah Utara. Jurnal Ekonomi Pembangunan Vol 5 No. 2 Juni 2020 ISSN 2503-3093 (online) Hlm. 38-53.

[18] Matheus, Rupa Donatus Kantur, M. Basti, Maria Klara Salli. 2019. Pertanian Terpadu: Model Rancangbangun dan Penerapan Pada Zona Agroekosistem Lahan Kering. Penerbit Deepublish. Yogyakarta

[19] Matheus, Rupa Donatus Kantur, M. Basti, Maria Klara Salli. 2019. Pertanian Terpadu: Model Rancangbangun dan Penerapan Pada Zona Agroekosistem Lahan Kering. Penerbit Deepublish: Yogyakarta.

[20] Hidayat, M. T., \& Sutarjo, M. (2021). Participation and Coordination between Companies and the Cirebon City Government in Poverty Alleviation through Corporate Social Responsibility Programs. International Journal of Science and Society,3(1), 154-172. https://doi.org/10.200609/ijsoc.v3i1.280

[21] Mulyati, S., Antarsih, N. R., Karningsih, \& Nirmalasari, D. (2021). The Effect of Elderly Gymnastics on Menopausal Women on Decreased Body Fat. International Journal of Science and Society, 3(1), 126-137. https://doi.org/10.200609/ijsoc.v3i1.278 